\title{
Az mRNS-alapú génterápia dermatológiai alkalmazásának lehetôségei: fényvédelem újragondolva
}

\section{Dermatological application of mRNA-based gene therapy: Protection from UV-radiation-caused damages}

\author{
BOROS GÁBOR ${ }^{1}$, MIKO EDIT DR. ${ }^{1}$, HORKAY IRÉN DR. ${ }^{1}$, KARIKÓ KATALIN DR. ${ }^{2}$, \\ EMRI GABRIELLA DR. ${ }^{1}$, REMENYIK ÉVA DR. ${ }^{1}$
}
Debreceni Egyetem, Orvosi - és Egészségtudományi Centrum, Bôrgyógyászati Klinika, Debrecen ${ }^{1}$ University of Pennsylvania, Department of Neurosurgery, Philadelphia ${ }^{2}$

\section{ÖSSZEFOGLALÁS}

A világszerte növekvő számban jelentkezó UV sugárzás okozta betegségek új megelôzố és terápiás stratégia kifejlesztését indokolják. Az UVB által elöidézett leggyakoribb DNS léziók a ciklobután pirimidin dimerek (CPD), amelyek apoptózishoz, immunszuppresszióhoz, mutációhoz, ezáltal börbetegségek kialakulásához vezethetnek. Az élettanilag fontos fehérjék in vitro-szintetizált mRNS által történő expresszálása nagy terápiás lehetôséggel bír. Ennek az új génterápiás technológiának az alkalmazásával sikerült funkcionálisan aktív CPD-specifikus fotoliáz fehérjét kifejezni humán keratinocitákban. Ezen tanulmány összefoglalja, hogy az in vitro-szintetizált mRNS milyen fontos és elönyös eszköze lehet a modern terápiás eljárásoknak.

Kulcsszavak:

mRNS terápia - fotoliáz - fényvédelem UVB - ciklobután pirimidin dimerek

\section{SUMMARY}

Increasing worldwide prevalence of UV irradiationinduced diseases warrants development of novel preventive and therapeutic strategies. The most common UVB-caused DNA lesion is cyclobutane pyrimidine dimer (CPD), which triggers skin diseases by inducing apoptosis, immunosuppression and mutation. In vitro-synthesized $m R N A$ coding for physiologically important proteins has great therapeutic potential. Applying this novel mRNAbased gene therapy method, we could achieve functional CPD-specific photolyase production in cultured human keratinocytes. The present study demonstrates that in vitrosynthesized mRNA is an effective tool for modern therapeutic applications.

\author{
Key words: \\ mRNA therapy - photolyase - \\ photoprotection - UVB - cyclobutane \\ pyrimidine dimer
}

\section{Az mRNS-alapú génterápia elônyei és nehézségei}

A géntranszfer technológia nagy fejlődésen ment keresztül az utóbbi időben. A különböző génterápiára irányuló eljárások közül az mRNS használata túnik a legalkalmasabbnak a terápiás fehérjék expresszálására, enzimdefektusok javítására, vakcina készítmények kifejlesztésére. Mindezt a virális vektor- és plazmid DNS-alapú géntranszfer módszerekkel szembeni előnyös tulajdonságai teszik lehetôvé (1). Sokkal biztonságosabb, mert nem integrálódik a genomba, kizárólag a kódolt fehérje gyors és hatékony szintézise történik meg a citoplazmában, továbbá tranziensen transzfektálható primer és nem osztódó sejtekbe is. Ezen kívül az mRNS-nek funkciója betöltéséhez nincs szükség sejtmagi lokalizációra, transzkripcióra $(2,3)$. Az említett előnyös tu- lajdonságok ellenére az in vitro-szintetizált mRNS sikeres in vivo alkalmazása korlátozott, hiszen különbözô RNS szenzorok aktiválása révén erôs immunválasz-reakciókhoz vezet. Ezen szenzorok legismertebb képviselői a Toll-like receptorok (TLR3, TLR7, TLR8), RIG-I (retinoic acid-inducible gene 1), IFIT1 és IFIT5 (interferon-induced protein with tetratricopeptid repeats 1 és 5), valamint a PKR (protein kinase RNA-activated) $(4,5)$. További problémát jelent, hogy a labilis szerkezete sem teszi alkalmassá klinikumban való felhasználását, génterápiás alkalmazását. Ezidáig az exogén mRNS terápiás lehetôségeinek kutatása elsôsorban a daganatellenes immunterápiára irányult, ahol antigént kódoló mRNS-t vittek be immunsejtekbe ex vivo (6). Az mRNS stabilitásának növelésével - az 5' végén található

Levelező szerző: Boros Gábor, DE OEC Bőrgyógyászati Klinika, 4032 Debrecen, Nagyerdei krt. 98. e-mail: gaba@med.unideb.hu 
„sapka” struktúra kémiai módosításával, valamint a 3' véghez kötött hosszabb poli (A) „farok” használatával - ígéretesebb terápiás célú felhasználásra nyílt esély (6). Azonban, ezen módosítások ellenére is, az in vitro-szintetizált mRNS nukleázokkal szembeni érzékenysége magas fokú, transzlációs hatékonysága pedig alacsony maradt, ráadásul a nemkívánatos mellékhatások továbbra is jelentkeztek $(7,8)$. Az mRNS-alapú géntranszfer technológia in vivo alkalmazásával kapcsolatban Karikó és mtsai. tudományos munkája hozott áttörést. Az mRNS szerkezetébe uridin helyett egy, a természetben is előforduló módosított nukleozidot, pszeudouridint építettek be. A pszeudouridin-módosítással sokkal hatékonyabb fehérje transzlációt értek el a nem módosított, vagy más kémiai módosítást tartalmazó mRNS-hez képest. A beépített pszeudouridin növelte az mRNS stabilitását, míg immunogenitását jelentősen csökkentette (9). Ezeket az előnyöket felhasználva Warren és mtsai. a transzkripciós faktorok expresszálásához keratinociták indukálható pluripotens sejtekké (iPSC, induced pluripotent stem cells) történô de-differenciálása, míg Wang és mtsai. egerekben indukált tüdődaganat növekedésének gátlása céljából használt pszeudouridint- es 5-metilcitidint-tartalmazó RNS-eket (10, 11). Kormann és mtsai más módosítású uridint épített be az in vitro-szintetizált mRNS-be, amely a surfactant protein B (SP-B) fehérjét kódolta, majd aeroszol technikával SP-B deficiens egerek tüdejébe juttatta, ami magas túlélési rátát eredményezett (12). Ugyanez a munkacsoport az allergia okozta asztma kezelésére is ígéretes terápiás alkalmazást fejlesztett ki módosított FOXP3 mRNS segítségével (13). Ezekben a közleményekben használt in vitro-szintetizált mRNS-ek már jelentős mértékben fokozták a kódolt fehérjék kifejeződését, viszont az RNS-szenzorok aktivitása még mindig detektálható volt. Karikó és mtsai. 2011-ben közölt munkájában demonstrálta, hogy az in vitro-szintetizált, pszeudouridin-módosított mRNS HPLC (high-performance liquid chromatography) segítségével történő tisztítása teljes mértékben megszünteti az mRNS immunogén természetét (14), és nanogramm mennyiségú mRNS használata is elegendônek bizonyult szignifikáns biológiai hatás eléréséhez egerekben (15). Eritropoetin fehérjét kódoló mRNS-t intraperitoneálisan juttatott egerekbe és majmokba, amelyek vérében még a negyedik napon is kimutatta a kódolt fehérjét, amely funkcionálisan aktív volt (15). A pszeudouridin-módosítás és HPLC tisztítás együttes alkalmazásának köszönhetően nemcsak az mRNS immunogenitását sikerült kiküszöbölni, de a kódolt fehérje elleni neutralizáló antitestek sem termelődtek (15). Az mRNS-alapú terápia embereken való alkalmazása természetesen még várat magára, de eddigi ismereteink új távlatokat nyithatnak a modern, mRNS-alapú készítmények kifejlesztésében és egyre közelebb visznek minket a klinikumban való használatuk megvalósításához.

\section{UV-sugárzást követô DNS károsodás és reparáció}

A pszeudouridin-módosított, HPLC-tisztított mRNS nagy szerepet játszhat a bőrbetegségek megelőzésében és terápiájában is. Patogenetikai szempontból a bőrt éró egyik legáltalánosabb környezeti tényező a napfény ult- raibolya sugárzása, amelynek biológiai hatásai hullámhossztól függően eltérőek (16). Az UVB-sugárzás (280$320 \mathrm{~nm}$ ) a DNS-ben közvetlenül elnyelődve ciklobután pirimidin dimereket (CPD) és 6-4-pirimidin-pirimidon (64 PP) fotoproduktumokat indukál (17). Mivel az UV-irradiáció hatására nagyobb számban keletkezik CPD, mint 64 PP, lassabban javítódik és nagyobb a mutagenitása is, jelentős szerepe van a sugárzás okozta károsodásokban (18, 19). A CPD-k a legkárosabb és leggyakoribb UVBokozta DNS-léziók közé tartoznak, nagymértékben hozzájárulnak az UV sugárzásnak kitett bőrben bekövetkezó akut válaszreakciókhoz (napégés, apoptózis, hiperplázia) (20-23). Hosszan tartó jelenlétük gyulladásos folyamatok indukálásához, immunszuppresszióhoz, illetve mutációhoz, ezáltal bőrbetegségek kialakulásához vezethet (2426). Az UVB káros hatásaival szemben a méhlepényes emlősök, így az ember is, kizárólag a nukleotid reparációs rendszer (NER) múködésére számíthat (27-29). A NER bonyolult és komplex mechanizmusának eredményeképpen az UVB által okozott CPD-k javítása több napig is eltart (30). Az UVB-indukált DNS léziók javítását a fotoliáz fehérjék is képesek elvégezni. Ezek olyan DNS javító enzimek, amelyek egy gyors, fényfüggố reakcióban (fotoreaktiváció) képesek a DNS szekvencia megváltoztatása nélkül specifikusan felismerni és kijavítani a fotoproduktumokat $(31,32)$. Ezek az enzimek azonban hiányoznak a méhlepényes emlősökből (33).

3. Nukleozid-módosított fotoliáz mRNS in vitro vizsgálatai és alkalmazásának lehetôségei a bőr sejtjeiben

Munkacsoportunk a fentebb leírt pszeudouridin-módosított, HPLC-tisztított mRNS-alapú génterápiás módszert olyan kísérleti rendszerben tesztelte, ahol az mRNS a fotoliáz fehérjét kódoló génszekvenciát tartalmazta. A Potorous tridactylus fotoliáz génjét kódoló mRNS-t kollaboráció keretében Karikó Katalin laboratóriuma in vitrotranszkripcióval hozta létre. A szekvencia kodon-optimalizálásával, az mRNS pszeudouridin-módosításával, hosszú poly(A) farok és cap1 struktúra kialakításával, valamint az mRNS HPLC tisztításával összességében magas transzlációs hatékonyságot, és biológiai stabilitást sikerült elérni, amit a DE OEC Bőrgyógyászati Klinika kutatócsoportja igazolt (34). Kísérleteink első fázisában kimutattuk, hogy a transzfektált, majd fotoreaktivált humán keratinocitákban a CPD-k száma több mint 60\%-kal csökkent a fotoliáz aktivációjához szükséges energiaforrást nélkülöző sejtekhez képest, ami bizonyította, hogy a transzlált fehérje funkcionálisan is aktív. A fotoreaktiváció szignifikánsan csökkentette az UVB dózis antiproliferatív hatását (34). A fotoliáz mRNS keratinocitákba juttatása alkalmasnak tûnik az UVB-indukálta CPD léziók eltávolítására humán keratinocitákban, ami előrevetíti alkalmazási lehetőségét a bőrdaganatok megelőzésében. A CPD-fotoliázt expresszáló sejtek kiváló modellrendszerként is szolgálnak az UVB sugárzás okozta hatásmechanizmusok vizsgálatára, mivel lehetővé teszik a CPD függő és független UVB hatások elkülönítését. Munkacsoportunk erre irányuló vizsgálatai folyamatban van- 
nak. Ismert, hogy a NER genetikailag meghatározott eltérései (Xeroderma pigmentosum, Cockayne's szindróma, trichothiodisztrófia), erős UV-fényérzékenységgel és a bőrdaganatok kialakulására való fokozott hajlammal járnak $(35,36)$. A fotoliáz mRNS in vivo alkalmazásának bevezetése új fényvédelmi stratégiát jelenthet, amely az akut napfénykárosodás és bőrdaganatok kialakulásának kockázatát csökkentheti, ezáltal a NER mutációi következtében kialakuló betegségekben szenvedôk részére új, hosszantartó fényvédelmi eszközzé válhat. A módosított fotoliáz mRNS in vivo bőrsejtekbe juttatásának a kidolgozása új utat nyithatna más fehérjét kódoló mRNS-alapú terápia megvalósítására is. A különböző bőrbetegségekhez kapcsolt, specifikus fehérjéket kódoló mRNS-ek alkalmazása így ígéretes terápiás eszköz lehet olyan betegségek gyógyításában is, mint az epidermolysis bullosa, Marfan-szindróma, Duchenne-betegség vagy tüdő emphysema. Napjainkban a bőrön át történő anyagbevitel intradermális injekcióval, mikrotûkkel vagy génpuskával történik. Az eljárások közül a legkevésbé invazív természettel a mikrotûk rendelkeznek, amelyek elég hosszúak ahhoz, hogy a bőr felsô rétegén áthatoljanak, de még ne okozzanak nagy fájdalmat $(37,38)$. Ezen technikák további hátránya, hogy a bőr mélyebb rétegeibe hatolnak, míg az általunk kívánt hatás eléréséhez a fotoliáz fehérjét kódoló mRNS molekulákat a bőr epidermiszének bazális membrán vagy e fölötti rétegek sejtjeihez kellene eljuttatni, hiszen ezek a sejtek az UVB-sugárzás fô targetjei. A nukleozid-módosított mRNS széleskörú preventív és terápiás alkalmazásához olyan módszert kell kifejleszteni, amely a stratum corneum barrier funkciójának kiküszöböléséhez nem igényel ilyen drasztikus eljárásokat.

A kézirat az OTKA 105872 és a TÁMOP-4.2.2A11/1/KONV-2012-0031 azonosító számú kutatási pályázat támogatásával készült

\section{IRODALOM}

1. Schott J. W., Galla M., Godinho T.: Viral and non-viral approaches for transient delivery of mRNA and proteins. Curr Gene Ther (2011) 11(5), 382-398.

2. Tavernier G., Andries O., Demeester J.: mRNA as gene therapeutic: how to control protein expression. J Control Release (2011) 150(3), 238-247.

3. Kuhn A. N., Beibetaert T., Simon P.: mRNA as a versatile tool for exogenous protein expression. Curr Gene Ther (2012) 12(5), 347-361.

4. Kawai T., Akira S.: The role of pattern-recognition receptors in innate immunity: update on Toll-like receptors. Nat Immunol (2010) 11(5), 373-384.

5. Brennan K., Bowie A. G.: Activation of host pattern recognition receptors by viruses. Curr Opin Microbiol (2010) 13(4), 503-507.

6. Kreiter S., Diken M., Selmi A.: Tumor vaccination using messenger RNA: prospects of a future therapy. Curr Opin Immunol (2011) 23(3), 399-406.

7. Kariko K., Ni H., Capodici J.: mRNA is an endogenous ligand for Toll-like receptor 3. J Biol Chem (2004) 279(13), 1254212550 .

8. Diebold S. S., Kaisho T., Hemmi H.: Innate antiviral responses by means of TLR7-mediated recognition of single-stranded RNA. Science (2004) 303(5663), 1529-1531.
9. Kariko K., Muramatsu H., Welsh F. A.: Incorporation of pseudouridine into mRNA yields superior nonimmunogenic vector with increased translational capacity and biological stability. Mol Ther (2008) 16(11), 1833-1840.

10. Warren L., Manos P. D., Ahfeldt T.: Highly efficient reprogramming to pluripotency and directed differentiation of human cells with synthetic modified mRNA. Cell Stem Cell (2010) 7(5), 618-630.

11. Wang Y., Su H. H., Yang Y.: Systemic delivery of modified mRNA encoding herpes simplex virus 1 thymidine kinase for targeted cancer gene therapy. Mol Ther (2013) 21(2), 358367.

12. Kormann M. S., Hasenpusch G., Aneja M. K.: Expression of therapeutic proteins after delivery of chemically modified mRNA in mice. Nat Biotechnol (2011) 29(2), 154-157.

13. Mays L. E., Ammon-Treiber S., Mothes B.: Modified Foxp3 mRNA protects against asthma through an IL-10-dependent mechanism. J Clin Invest (2013) 123(3), 1216-1228.

14. Kariko K., Muramatsu H., Ludwig J.: Generating the optimal mRNA for therapy: HPLC purification eliminates immune activation and improves translation of nucleoside-modified, protein-encoding mRNA. Nucleic Acids Res (2011) 39(21), e142.

15. Kariko K., Muramatsu H., Keller J. M.: Increased erythropoiesis in mice injected with submicrogram quantities of pseudouridinecontaining mRNA encoding erythropoietin. Mol Ther (2012) 20(5), 948-953.

16. Matsumura Y., Ananthaswamy $H . N$. .: Toxic effects of ultraviolet radiation on the skin. Toxicol Appl Pharmacol (2004) 195(3), 298-308

17. Cadet J., Anselmino C., Douki T.: Photochemistry of nucleic acids in cells. J Photochem Photobiol B (1992) 15(4), 277-298.

18. Mitchell D. L.: The relative cytotoxicity of (6-4) photoproducts and cyclobutane dimers in mammalian cells. Photochem Photobiol (1988) 48(1), 51-57.

19. Sage E.: Distribution and repair of photolesions in DNA: genetic consequences and the role of sequence context. Photochem Photobiol (1993) 57(1), 163-174.

20. Ueda M., Matsunaga T., Bito T.: Higher cyclobutane pyrimidine dimer and (6-4) photoproduct yields in epidermis of normal humans with increased sensitivity to ultraviolet B radiation. Photodermatol Photoimmunol Photomed (1996) 12(1), 22-26.

21. Kunisada M., Kumimoto H., Ishizaki K.: Narrow-band UVB induces more carcinogenic skin tumors than broad-band UVB through the formation of cyclobutane pyrimidine dimer. J Invest Dermatol (2007) 127(12), 2865-2871.

22. Lo H. L., Nakajima S., Ma L.: Differential biologic effects of CPD and 6-4PP UV-induced DNA damage on the induction of apoptosis and cell-cycle arrest. BMC Cancer (2005) 5, 135 .

23. Marrot L., Meunier J. R.: Skin DNA photodamage and its biological consequences. J Am Acad Dermatol (2008) $58(5$ Suppl 2), S139-148.

24. Protic-Sabljic M., Tuteja N., Munson P. J.: UV light-induced cyclobutane pyrimidine dimers are mutagenic in mammalian cells. Mol Cell Biol (1986) 6(10), 3349-3356.

25. Emri G., Wenczl E., Van Erp P.: Low doses of UVB or UVA induce chromosomal aberrations in cultured human skin cells. J Invest Dermatol (2000) 115(3), 435-440.

26. You Y. H., Lee D. H., Yoon J. H.: Cyclobutane pyrimidine dimers are responsible for the vast majority of mutations induced by UVB irradiation in mammalian cells. J Biol Chem (2001) 276(48), 44688-44694.

27. Mullenders L. H., Hazekamp-van Dokkum A. M., Kalle W. H.: UV-induced photolesions, their repair and mutations. Mutat Res (1993) 299(3-4), 271-276.

28. Hoeijmakers J. H.: Genome maintenance mechanisms for preventing cancer. Nature (2001) 411(6835), 366-374.

29. Nouspikel T.: DNA repair in mammalian cells : Nucleotide excision repair: variations on versatility. Cell Mol Life Sci (2009) 66(6), 994-1009.

30. Nishinaga M., Kurata R., Onishi K.: Establishment of a microplate-formatted cell-based immunoassay for rapid analysis of nucleotide excision repair ability in human primary cells. Photochem Photobiol (2012) 88(2), 356-362. 


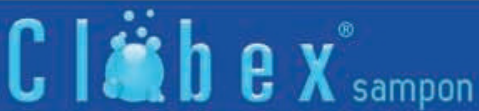
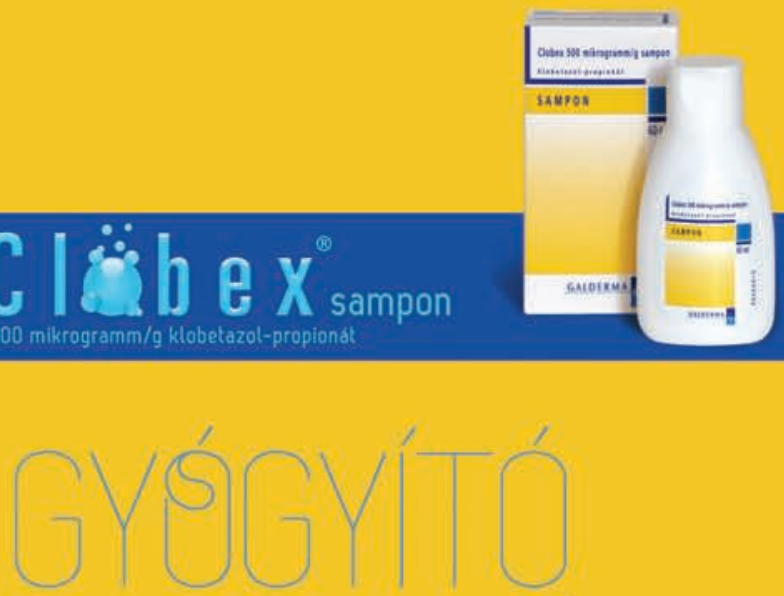

w

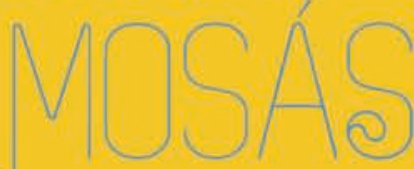

A HAJAS FE JBÖR PSORIASIS

AKUTT ES FENNTARTO KEZELESEBEN

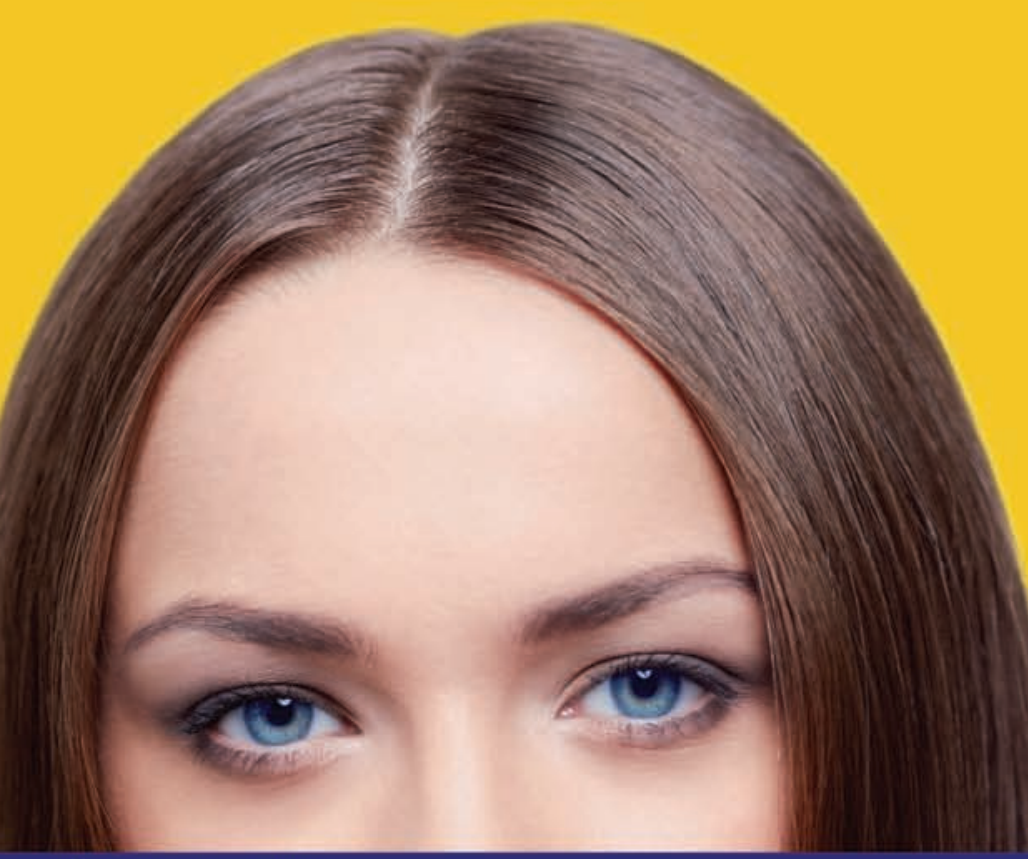

Röviditett alkalmazási elöírás:

Clobex 500 mikrogramm/g sampon. Egy gramm sampon 500 mikrogramm klobetazol-propionatot tartalmaz. Terápiás javallat: A hajas fejbỡr mérsêkelt fokù psoriasisảnak helyl kezelése felnôtteknél. Adagolás és alkalmazás: Külsóleg. kizárólag a fejbốrōn alkalmazható. A Clobex 500 mikrogramm/g sampont közvellenül à száraz hajas fejbớrre kell felvinni, és bemasszirozni naponta egyszer. figyelmet forditva arra. hogy az érintett területekre mindenhova jusson. Egy fél evốkanälnak megfeleló mennylség (kb. $7.5 \mathrm{ml})$ alkalmanként elegendố a teljes hajas fejbốrre. A felvitelt kôvetóen kezet kell mosni, és 15 percen keresztüt hagyni kell hatn.

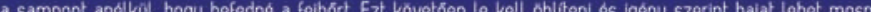
az strattinos sampor

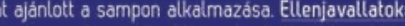
a készitmény hatoanyagával vagy bármely segédanyagával szembenl tưlérzékenység: bakteriális, virális bốrbetegségek (varicella, herpes simplex herpes zoster), gombás vagy parazita okozta fertózéses bớrbetegségek és specilflkus bốrbetegségek esełén. Nem szabad alkalmazni a szem körül. fekélyes sebeken és kết év alatti guermekeknél Terhesség Clabex 500 mikrogramm/g sampont a terhesség ideje alatt nem szabad alkalmazni, csak akkor, ha erre egyertelmúen szükség van. Szoptatás: A Clobex 500 mikrogramm/g sampont nem szábad felirni szoptató nö́k számára, hacsak nem egyérteimúen indokolt. Nem kivánatos hatások, mellékhatások: gyakori mellékhatás ( $\geq 1 / 100-</ / 10)$ a bớr diszkomfort érzése, akne/follicultiss, szemek csipó/ égetố érzése.Nem gyakori mellékhatások ( $2 / / 1000-</ / 10)$ : lokälis irritáció, pruritus. utricaria. telanglectasia. bór atrophia. Kizárólàg orvosi rendelvényhez kötôtt gyógyszer (V). OGYl engedély szám: 0GYl-T-20383/02. Alkämazási elöirás dátuma: २०13. április 4 . Kèrjouk, olvassa el a teljes alkalmazási elöirästl TB támogatás: normativ. 25\%. Támogatás összege: $625 \mathrm{Ft}$. Téritési dij: $1.875 \mathrm{Ft}$. Bruttó fogyasztói ấ: $2500 \mathrm{Ft}$. Az aktuális ârakról kérjuk, tảjékozódjon a www.oep.hu oldalän! Közquógyellátás terhère felirható gyógyszer. Amennyiben gyógyszerünkkel kapcsolatban mellékhatás lépne fel, kérjük, késedelem nélkül az alábbi e-mail címen jelentse be: pharmacovigilance@ewopharma.hu

Forgalomba hozatall engedély jogosultja:

\section{GALDERMA}

Galderma International

Tour Europlaza - La Défense 4

20 avenue André Prothin 92927 La Défense

Cedex. Franclaorszadg

EWO/CLOBEX/2013/06

A dokumentum lezárásának ideje: 2013.09. 24.
31. Sinha R. P., Hader D. P.: UV-induced DNA damage and repair: a review. Photochem Photobiol Sci (2002) 1(4), 225236.

32. Hearst J. E.: The structure of photolyase: using photon energy for DNA repair. Science (1995) 268(5219), 1858-1859.

33. Li Y. F., Kim S. T., Sancar A.: Evidence for lack of DNA photoreactivating enzyme in humans. Proc Natl Acad Sci U S A (1993) 90(10), 4389-4393.

34. Boros G., Miko E., Muramatsu H.: Transfection of pseudouridine-modified mRNA encoding CPD-photolyase leads to repair of DNA damage in human keratinocytes: a new approach with future therapeutic potential. Journal of Photochemistry and Photobiology B: Biology 2013.

35. Hoeijmakers J. H.: Nucleotide excision repair. II: From yeast to mammals. Trends Genet (1993) 9(6), 211-217.

36. de Boer J., Hoeijmakers J. H.: Nucleotide excision repair and human syndromes. Carcinogenesis (2000) 21(3), 453-460.

37. Kim Y. C., Jarrahian C., Zehrung D.: Delivery systems for intradermal vaccination. Curr Top Microbiol Immunol (2012) $351,77-112$.

38. Tuan-Mahmood T. M., McCrudden M. T., Torrisi B. M.. Microneedles for intradermal and transdermal drug delivery. Eur J Pharm Sci 2013.

Érkezett: 2013. 05. 24

Közlésre elfogadva: 2013. 09. 30. 